\title{
LITERASI STATISTIS SISWA KELAS VIII SMP NEGERI 1 GRESIK
}

\section{THE STATISTICAL LITERACY OF $8^{T H}$ GRADE STUDENTS OF SMP NEGERI 1 GRESIK}

\author{
Junaidah Wildani ${ }^{1}$, Illah Winiati Triyana ${ }^{2}$, Wilda Mahmudah ${ }^{3}$ \\ 1Universitas Qomaruddin, j.nida.wildani@gmail.com \\ 2Universitas Qomaruddin, illahwtriyana@gmail.com \\ 3Universitas Qomaruddin, wilda0403@gmail.com
}

\begin{abstract}
Abstrak. Penelitian ini bertujuan mengukur literasi statistis siswa kelas VIII di SMP Negeri 1 Gresik. Subjek penelitian adalah siswa kelas VIII J. Jenis penelitian ini adalah penelitian deskriptif dan pendekatan yang digunakan untuk menganalisis data adalah pendekatan kuantitatif. Literasi statistis siswa diukur dengan tes literasi statistis yang validitas dan reliabilitasnya telah teruji. Validitas tes dievaluasi oleh dua orang ahli secara formatif sedangkan reliabilitas tes dihitung dengan menggunakan rumus Kuder Richardson (KR 20). Penilaian validitas tes menunjukan bahwa tes valid, dan uji reliabilitas menunjukan bahwa koefisien reliabilitas $r_{i}=0,57$ yang menunjukan tes cukup reliabel. Hasil tes menunjukan bahwa skor rata-rata tes literasi statistis siswa adalah 63,2 $(S D=8,28)$. Hasil ini menunjukan bahwa siswa kelas VIII J SMPN 1 Gresik memiliki kemampuan literasi satistis yang cukup.
\end{abstract}

Kata kunci: literasi statistis, penelitian deskriptif-kuantitatif

\begin{abstract}
This study aims to measure eighth grade students of SMP Negeri 1 Gresik's mathematical literacy. The subject of this research is students from grade VIII J. This is descriptive research with quantitative approach to analyse its data. Students' statistical literacy was measured using a statistical literacy test which validity and reliability was already tested. The test's validity was evaluated formatively by two experts, meanwhile the test's reliability coefficient was calculated using Kuder Richardson (KR 20) formula. Validity assessment of the test shows that the test is valid, and the reliability measurement obtained the reliability coefficient of $r_{i}=0,57$ which indicates that the test is quite reliable. The result of the test shows that the average score of students' statistical literacy is $63,2(M=8,28)$. This number indicates that grade VIII J students of SMPN 1 Gresik is sufficient in their statistical literacy.
\end{abstract}

Keywords: statistical literacy, descriptive-quantitative research 


\section{PENDAHULUAN}

Seiring dengan berkembangnya teknologi informasi, semakin mudah pula penyebaran informasi dan berita di kalangan masyarakat. Tidak jarang, sebuah berita dilengkapi dengan data yang disajikan dalam berbagai bentuk. Untuk masyarakat awam yang tidak memahami tentang penyajian dan bagaimana menafsirkan sebuah data, hal ini dapat menimbukan kebingungan dan penafsiran yang kurang tepat. Tidak jarang pula, minimnya pemahaman masyarakat tentang data juga dimanfaatkan pihak-pihak tidak bertanggung jawab untuk menyebar berita yang kurang benar dan menyesatkan. Untuk itulah pentingnya pengenalan pengetahuan dan pemahaman tentang data dan juga membangun literasi seseorang sejak dini.

Cabang ilmu pengetahuan yang mempelajari tentang data adalah statistika. American Statistical Association (ASA)- mendefinisikan statistika sebagai "the science of learning from data, and of measuring, controlling and communicating uncertainty". Definisi tersebut menjelaskan bahwa statistika adalah ilmu pengetahuan untuk belajar dari data, mengukur data, mengendalikan dan mengkomunikasikan data. Sedangkan menurut Romijin \& Jan-Willem (2014) statistika adalah cabang ilmu matematika yang mempelajari tentang data; bagaimana mengumpulkan, mengelola, menganalisis, menginterpretasi data dan menyajikan data.

Di Indonesia, statistika diajarkan mulai dari tingkat Sekolah Dasar (SD) sampai Sekolah Mengengah Atas (SMA). Hal ini menunjukan pentingnya posisi ilmu statistika dalam kehidupan. Statistika memiliki berbagai manfaat dalam kehidupan manusia (Sariningsi dan Herdiman, 2017), mulai dari hal-hal sederhana sampai pada hal-hal yang lebih kompleks. Bahkan, statistika memegang peranan yang sangat penting dalam perkembangan ilmu pengetahuan dan tehnologi. Hal ini dikarenakan ilmu statistika dapat digunakan sebagai alat untuk menjawab pertanya'an-pertanya' an saintifik dalam sebuah penelitian (Field, 2009).

Kompetensi dasar statistika penting untuk dimililiki untuk dapat memahami, menganalisis, interpretasi, dan membuat kesimpulan terhadap berbagai informasi terkait dengan statistik serta dapat meberi makna permasalahan yang dimunculkan melalu informasi statistik di berbagai media literasi (Takaria dan Talakua, 2018). Untuk itu, munculah literasi statistis sebagai suatu konsep (Takaria dan Talakua, 2018) yang memuat kemampuan untuk membaca dan menginterpretasi data statistik di media harian lainnya dan ditampilkan melalui grafik , tabel, pernyataan, survey, dan studi statistik (Unece, 2012).

Literasi statistis disini dikembangkan dari konsep literasi matematis yang diusung oleh The Organisation for Economic Co-operation and Development (OECD) pada tahun 2000. Literasi matematis didefinisikan sebagai kemampuan seseorang dalam merumuskan, menerapkan, dan menafsirkan matematika dalam berbagai konteks. Kemampuan tersebut meliputi penalaran matematis, menggunakan konsep-konsep, 
prosedur-prosedur, fakta-fakta dan alat-alat matematika untuk menjabarkan, menjelaskan, dan memprediksi fenomena-fenomena (OECD, 2013).

Untuk mengetahui literasi siswa di seluruh dunia, OECD melakukan penilaian terhadap literasi siswa, termasuk literasi matematis di seluruh dunia sejak tahun 2000. Program penilaian ini disebut dengan The Program for international Students Assessment (PISA). Indonesia adalah salah satu negara yang ikut berpartisipasi dalam PISA. Namun sayangnya, hasil tes pada PISA menunjukan bahwa literasi siswa di Indonesia termasuk rendah. Hasil survey PISA pada tahun 2003 (OECD, 2004) menunjukan bahwa siswa Indonesia berada di peringkat 38 dari 41 negara yang berpartisipasi dalam PISA. Pada tahun 2012, literasi matematis siswa Indonesia berada di peringkat 64 dari 65 negara (OECD, 2014).

Karena pada literasi matematis yang diukur dalam PISA juga mencakup statistika, maka fakta di atas juga mengindikasikan kemungkinan akan rendahnya literasi statistis siswa di Indonesia. Untuk itu diperlukan gambaran umum tentang kemampuan literasi statistis siswa agar pemerintah, para pendidik dan pakar dapat mengambil tindakan untuk membangun dan mengembangkan literasi statistis siswa. Dengan demikian, penelitian ini bertujuan mengukur kemampuan literasi statistis siswa kelas VIII di SMP Negeri 1 Gresik.

Mengingat statistika adalah cabang ilmu matematika, maka definisi literasi matematis tersebut juga mencakup ilmu statistika. Dengan mengadaptasi definisi literasi matematis di atas dan melihat definisi statistika, maka yang dimaksud dengan literasi statistis disini adalah kemampuan seseorang dalam menafsirkan dan menggunakan statistika dalam berbagai konteks. Kemampuan tersebut meliputi penggunaan prosedur-prosedur statistika untuk menjabarkan, menjelaskan, dan memprediksi fenomena-fenomena.

\section{METODE}

Penelitian ini dilakukan di SMP Negeri 1 Gresik pada tanggal 2-6 Mei 2019 dengan subjek yang dipilih adalah dari siswa kelas VIII J SMP Negeri 1 Gresik.

Jenis penelitian ini adalah penelitian deskriptif yaitu penelitian yang bertujuan menjelaskan suatu gejala atau peristiwa. Dalam penelitian ini, gejala/peristiwa yang dijelaskan adalah kemampuan literasi statistis siswa. Pendekatan yang digunakan untuk mengelola data dan menarik kesimpulan pada penelitian ini adalah pendekatan kuantitatif.

Instrumen yang digunakan untuk mengumpulkan data penelitian ini tes literasi statistis. Tes ini terdiri dari 13 soal dimana soal-soal tersebut dilengkapi dengan konteks yang melatar belakangi setiap soal. Bentuk tes adalah campuran soal essay, pilihan ganda, dan benar/salah. Soal-soal dari tes ini diadaptasi dari tes PISA tahun 2006 dan 2012 pada domain matematika dan soal dipilih dari materi statistika. Pertimbangan lain yang 
digunakan untuk memilih soal adalah kesesuannya dengan standar kompetensi dan indikator pada materi pelajaran statistika di kelas VIII. Berikut disajikan kisi-kisi soal yang digunakan dalam tes literasi statistis pada penelitian ini.

Tabel 1. Kisi-Kisi Tes Literasi statistis

\begin{tabular}{|c|c|c|c|}
\hline No & $\begin{array}{l}\text { Komptensi } \\
\text { Dasar }\end{array}$ & Indikator Soal & Deskripsi dan Sumber Soal \\
\hline 1. & $\begin{array}{l}\text { Memahami } \\
\text { teknik penyajian } \\
\text { data dua variabel } \\
\text { menggunakan } \\
\text { tabel, grafik } \\
\text { batang, diagram } \\
\text { lingkaran, dan } \\
\text { grafik garis } \\
\text { dengan } \\
\text { komputer serta } \\
\text { menganalisis } \\
\text { hubungan antar } \\
\text { variabel }\end{array}$ & $\begin{array}{l}\text { Menjelaskan } \\
\text { teknik penyajian } \\
\text { data }\end{array}$ & $\begin{array}{l}\text { Menjelaskan alasan mengapa } \\
\text { memilih tehnik penyajian data } \\
\text { tertentu } \\
\text { Sumber: PISA } 2006 \text { released } \\
\text { item } \\
\text { M505: Litters }\end{array}$ \\
\hline 2. & $\begin{array}{l}\text { Mengumpulkan, } \\
\text { mengolah, } \\
\text { menginterpretasi, } \\
\text { dan menyajikan } \\
\text { data hasil } \\
\text { pengamatan }\end{array}$ & $\begin{array}{l}\text { Menafsirkan data } \\
\text { dari diagram } \\
\text { batang }\end{array}$ & $\begin{array}{l}\text { Membaca diagram batang dan } \\
\text { membandingkan tinggi dan } \\
\text { batang } \\
\text { Sumber: PISA } 2012 \text { released } \\
\text { item Chart No.2 }\end{array}$ \\
\hline 3. & $\begin{array}{l}\text { dalam bentuk } \\
\text { tabel, diagram, } \\
\text { dan grafik dari } \\
\text { dua variabel serta } \\
\text { mengidentifikasi }\end{array}$ & & $\begin{array}{l}\text { Menafsirkan diagram batang } \\
\text { dan membuat prediksi } \\
\text { Sumber: PISA } 2012 \text { released } \\
\text { item Chart No.5 }\end{array}$ \\
\hline 4 & $\begin{array}{l}\text { hubungan antar } \\
\text { variabel }\end{array}$ & $\begin{array}{l}\text { Mengolah data } \\
\text { dari diagram } \\
\text { batang }\end{array}$ & $\begin{array}{l}\text { Menganalisis pernyataan yang } \\
\text { berbeda terkait diagram batang }\end{array}$ \\
\hline 6 & & & $\begin{array}{l}\text { Sumber: PISA } 2012 \text { released } \\
\text { item Pinguin No. } 4\end{array}$ \\
\hline 7 & & & \\
\hline 8 & & $\begin{array}{l}\text { Menyajikan data } \\
\text { hasil pengamatan } \\
\text { dalam diagram } \\
\text { dan grafik }\end{array}$ & $\begin{array}{l}\text { Menggambar grafik atau } \\
\text { diagram } \\
\text { Sumber: PISA } 2009 \text { Assessment } \\
\text { framework } \\
\text { Math ex } 25\end{array}$ \\
\hline 9 & & $\begin{array}{l}\text { Mengolah data } \\
\text { dari diagram }\end{array}$ & $\begin{array}{l}\text { Mengelolah data dari diagram } \\
\text { batang dan lingkaran }\end{array}$ \\
\hline
\end{tabular}




\begin{tabular}{llll}
\hline & & & \\
\hline & $\begin{array}{l}\text { batang } \\
\text { lingkaran }\end{array}$ & dan & Sumber: PISA 2006 released \\
& & item M438 Export No. 2 \\
& $\begin{array}{l}\text { Mengolah data } \\
\text { hasil pengamatan }\end{array}$ & $\begin{array}{l}\text { Menarik kesimpulan dari } \\
\text { informasi tentang rata-rata }\end{array}$ \\
\hline $\mathbf{1 1}$ & & $\begin{array}{l}\text { Sumber: PISA 2006 released } \\
\text { item M479 Student height No.1 }\end{array}$ \\
& & \\
\hline $\mathbf{1 3}$ & & \\
\hline
\end{tabular}

Sebelum tes literasi statistis digunakan, dilakukan uji validitas dan reliabilitas terhadap tes. Uji validitas dilakukan secara formatif oleh dua orang ahli menggunakan lembar penilaian validitas tes. Lembar penilaian validitas ini diadopsi dari Lestariningsih (2019) yang menetapkan tiga aspek penilaian, yaitu: isi materi, konstruksi, dan Bahasa. Tes literasi statistis dikatakan valid jika kedua ahli menyatakan bahwa semua kriteria valditas tes telah terpenuhi.

Karena tes literasi statistis menggunakan penilaian dikotomi ( 1 untuk jawaban benar, 0 untuk jawaban salah), realiabilitas tes dihitung dengan rumus Kuder Richardson (KR 20) sebagai berikut

$$
r_{i}=\frac{k}{k-1}\left(\frac{s_{t}^{2}-\sum p_{i} q_{i}}{s_{t}^{2}}\right)
$$

Dimana

$$
\begin{array}{ll}
k & \text { : jumlah item dalam instrument } \\
p_{i} & \text { : proporsi banyaknya subjek yang menjawab pada item } i \\
q_{i} & : 1-p_{i} \\
s t^{2} & : \text { varians total }
\end{array}
$$

(Sugiyono, 2017)

Arikunto (2009; 245) mengelompokan nilai reliabilitas kedalam empat tingkat seperti yang dapat dilihat di tabel di bawah ini.

Tabel 2. Kriteria Nilai Reliabilitas

\begin{tabular}{cc}
\hline Rentang & Keterangan \\
\hline $0,80-1,00$ & Sangat tinggi \\
\hline $0,60-0,79$ & Tinggi \\
\hline $0,40-0,59$ & Cukup \\
\hline $0,20-0,39$ & Rendah \\
\hline $0,0-0,19$ & Sangat rendah \\
\hline
\end{tabular}

Pada penelitian ini, tes dapat digunakan jika tingkat reliabilitas adalah minimal cukup $\left(r_{i} \geq 0,40\right)$. 
Setelah tes literasi statistis dinyatakan valid dan reliabel, maka tes ini dapat digunakan untuk mengukur kemampuan literasi statistis siswa. Data kemampuan literasi statistis siswa yang berupa skor hasil tes kemudian diolah untuk dicari rata-rata (mean) skornya dengan rumus berikut

Dimana

$$
\bar{x}=\frac{\sum x_{i}}{n}
$$

$\bar{x} \quad=$ rata-rata skor hasil tes

$\sum x_{i}=$ jumlah total skor subjek

$n \quad=$ banyak subjek

(Sugiyono, 2017)

Dengan mengadopsi pengelompokan kategori nilai dalam Ujian Nasional (UN) oleh Badan Standar Pendidikan Nasional (2019), skor yang didapat kemudian dikelompokan menjadi empat kategori dengan kriteria sebagai berikut.

Tabel 3: Kriteria Nilai Hasil Tes Literasi statistis

\begin{tabular}{cc}
\hline Kriteria & Kategori \\
\hline $\mathbf{8 5}<\boldsymbol{x} \leq \mathbf{1 0 0}$ & Sangat baik \\
\hline $\mathbf{7 0}<\boldsymbol{x} \leq \mathbf{8 5}$ & Baik \\
\hline $\mathbf{5 5}<\boldsymbol{x} \leq \mathbf{7 0}$ & Cukup \\
\hline $\mathbf{0} \leq \boldsymbol{x} \leq \mathbf{5 5}$ & Kurang \\
\hline
\end{tabular}

Adapun simpangan baku (standard deviasi) skor dihitung dengan rumus berikut

$$
S D=\sqrt{\frac{\sum\left(x_{i}-\bar{x}\right)^{2}}{n}}
$$

Dengan:

$S D=$ Simpangan baku

$x_{i} \quad=$ Skor hasil tes tiap subjek

$\bar{x} \quad=$ Rata-rata skor hasil tes subjek

$n \quad=$ Jumlah subjek

(Sugiyono, 2017)

\section{HASIL DAN PEMBAHASAN \\ Validitas dan Reliabilitas Tes}

Untuk menguji validitas tes, dua orang ahli yaitu Dr. Lestariningsih, M.Pd yang merupakan dosen di Prodi Pendidikan Matematika STKIP PGRI Sidoarjo (Validator 1) dan Moch. Lutfianto, M.Pd yang merupakan dosen Prodi Pendidikan Matematika di STKIP Al Hikmah Surabaya (Validator 2) ditunjuk sebagai validator tes literasi statistik. Keduanya memiliki pengalaman ahli literasi matematis di perguruan tinggi masing-masing. 
Hasil validasi oleh masing-masing ahli dijabarkan dalam tabel berikut

Tabel 4: Hasil Penilaian Validasi

\begin{tabular}{|c|c|c|}
\hline Indikator & $\begin{array}{l}\text { Komentar dari } \\
\text { Validator } 1\end{array}$ & $\begin{array}{l}\text { Komentar dari } \\
\text { Validator } 2\end{array}$ \\
\hline \multicolumn{3}{|l|}{ Aspek: Isi materi } \\
\hline $\begin{array}{l}\text { Kesesuain soal dengan } \\
\text { komptensi dasar yang } \\
\text { telah ditetapkan }\end{array}$ & $\begin{array}{l}\text { Sebaiknya } \\
\text { diperhatikan kata } \\
\text { "dengan } \\
\text { komputer" }\end{array}$ & - \\
\hline $\begin{array}{l}\text { Kesesuaian soal dengan } \\
\text { tujuan pembelajaran yang } \\
\text { telah ditetapkan }\end{array}$ & - & $\begin{array}{l}\text { Ada beberapa } \\
\text { tujuan, terutama } \\
\text { yang berhubungan } \\
\text { dengan median yang } \\
\text { kurang diujikan ke } \\
\text { siswa }\end{array}$ \\
\hline \multicolumn{3}{|l|}{ Aspek: Konstruksi } \\
\hline $\begin{array}{l}\text { Kalimat tidak } \\
\text { menimbulkan penafsiran } \\
\text { ganda }\end{array}$ & - & $\begin{array}{l}\text { Ada beberapa yang } \\
\text { masih menimbulkan } \\
\text { penafsiran ganda }\end{array}$ \\
\hline $\begin{array}{l}\text { Penggunaan kalimat tanya } \\
\text { atau perintah }\end{array}$ & $\begin{array}{l}\text { Sebaiknya } \\
\text { dilengkapi dengan } \\
\text { tanda perintah (!) }\end{array}$ & $\begin{array}{l}\text { Ada kalimat yang } \\
\text { tidak diberi tanda } \\
\text { baca }\end{array}$ \\
\hline Mudah dipahami & $\begin{array}{l}\text { Sebaiknya } \\
\text { konsisten dalam } \\
\text { penulisan soal }\end{array}$ & - \\
\hline $\begin{array}{l}\text { Batasan soal yang } \\
\text { diberikan jelas }\end{array}$ & $\begin{array}{l}\text { Tambahkan alokasi } \\
\text { waktu untuk } \\
\text { mengerjakan }\end{array}$ & - \\
\hline \multicolumn{3}{|l|}{ Aspek: Bahasa } \\
\hline $\begin{array}{l}\text { Penggunaan kalimat } \\
\text { matematika yang benar }\end{array}$ & - & - \\
\hline $\begin{array}{l}\text { Penggunaan kaidah } \\
\text { bahasa Indonesia yang } \\
\text { baik dan benar }\end{array}$ & $\begin{array}{l}\text { Terdapat beberapa } \\
\text { kata yang perlu } \\
\text { diperbaiki }\end{array}$ & $\begin{array}{l}\text { Ada beberapa } \\
\text { singkatang dan kata } \\
\text { yang kurang baku }\end{array}$ \\
\hline $\begin{array}{l}\text { Penggunaan kata yang } \\
\text { dikenal siswa }\end{array}$ & - & - \\
\hline Komunikatif & - & - \\
\hline
\end{tabular}

Tes literasi statistis kemudian direvisi sesuai dengan komentar dan saran kedua validator. Berikut adalah perbaikan yang dilakukan terhadap tes literasi statistis sesuai dengan saran dan komentar validator. 
Tabel 5. Perbaikan pada Tes Literasi statistis

\begin{tabular}{|c|c|c|}
\hline $\begin{array}{l}\text { No. } \\
\text { Soal }\end{array}$ & Sebelum Perbaikan & Setelah Perbaikan \\
\hline \multirow[t]{2}{*}{1} & $\begin{array}{l}\text { Kalimat perintah "Berikan } \\
\text { satu alasan" }\end{array}$ & $\begin{array}{l}\text { Kalimat perintah "Berikan satu } \\
\text { alasan atau lebih" }\end{array}$ \\
\hline & $\begin{array}{l}\text { "siswa mengumpulkan data } \\
\text { tentang waktu dekomposisi } \\
\text { berbagai jenis sampah yang } \\
\text { dibuang orang-orang" }\end{array}$ & $\begin{array}{l}\text { "siswa mengumpulkan data } \\
\text { tentang waktu dekomposisi } \\
\text { berbagai jenis sampah yang } \\
\text { dibuang oleh masyarakat yang } \\
\text { ditunjukan dalam tabel } \\
\text { berikut" }\end{array}$ \\
\hline \multirow[t]{2}{*}{2} & “Penjualan album CD" & "Penjualan CD album" \\
\hline & $\begin{array}{l}\text { Penggunaan nama band } \\
\text { "Padi", "Dewa", "Sheila"dan } \\
\text { "Tipe-X" }\end{array}$ & $\begin{array}{l}\text { Penggunaan nama band } \\
\text { "Roker", "Antis", "Rainbow" } \\
\text { dan "Pencase" }\end{array}$ \\
\hline 3. & Penggunaan kata "cemas" & Penggunaan kata "khawatir" \\
\hline 5 & $\begin{array}{l}\text { "Pada tahun 2006, rata-rata } \\
\text { kurang dari } 80 \% \text { pasangan } \\
\text { pinguin membesarkan anak } \\
\text { pinguin" }\end{array}$ & $\begin{array}{l}\text { "Pada tahun 2006, persentasi } \\
\text { rata-rata pasangan pinguin } \\
\text { yang membesarkan seokor } \\
\text { anak pinguin kurang dari } 80 \% \text { " }\end{array}$ \\
\hline 8 & $\begin{array}{l}\text { Penggunaan kata "table" dan } \\
\text { "ketidakmerataan" }\end{array}$ & $\begin{array}{l}\text { Kata diganti menjadi } \\
\text { "tabel"dan "tidak meratanya" }\end{array}$ \\
\hline
\end{tabular}

Setelah tes literasi diperbaiki, tes dinyatakan memenuhi setiap indikator penilaian validasi. Selanjutnya dilakukan uji reliabilitas tes. Uji reliabilitas tes dilakukan dengan memberikan tes pada 30 siswa dari kelas VIII H (kelas non-subjek). Hasil tes kemudian dihitung dengan menggunakan rumus (1). Dari hasil perhitungan diperoleh koefisien reliabilitas tes literasi $r_{i}=0,57$ yang mengindikasikan bahwa tes literasi statistik cukup reliabel sehingga tes literasi statistik dapat digunakan untuk mengukur kemampuan literasi statistis siswa.

\section{Literasi statistis}

Tes literasi statistis yang valid dan reliabel kemudian diberikan pada subjek (kelas VIII J) yang berjumlah 31 siswa. Skala penilaian yang ditetapkan adalah 0-100. Rata-rata hasil tes literasi subjek kemudian dihitung menggunakan rumus (2). Hasil perhitungan menunjukan bahwa rata-rata hasil tes literasi statistis siswa adalah $63,2(\mathrm{SD}=8,28)$. Dengan skor tertinggi adalah 76,92 dan skor terendah adalah 53,85. Berdasarkan kriteria pengelompokan nilai pada tabel 3, maka dapat disimpulkan bahwa kemampuan literasi staistika siswa di kelas VIII J adalah sedang.

Dari 13 soal yang diberikan pada siswa, soal No. 8 adalah soal yang paling sult bagi dengan hanya tiga siswa menjawab benar pada soal ini. 
Pada soal ini, siswa diminta untuk menyajikan data dalam bentuk diagram.

\section{INDONESIA}

Indonesia berada di antara Malaysia dan Australia. Beberapa data populasi Indonesia dan distribusinya ditunjukan pada tabel berikut.

\begin{tabular}{|l|l|l|l|l|}
\hline \multicolumn{1}{|c|}{ Daerah } & \multicolumn{1}{|c|}{$\begin{array}{c}\text { Luas area } \\
\text { permukaan } \\
\left(\mathrm{km}^{2}\right)\end{array}$} & $\begin{array}{c}\text { Persentasi dari } \\
\text { luas total (\%) }\end{array}$ & $\begin{array}{c}\text { Populasi pada } \\
\text { tahun } 1980 \\
\text { (dalam juta) }\end{array}$ & $\begin{array}{c}\text { Persentasi dari } \\
\text { pipulasi total (\%) }\end{array}$ \\
\hline Jawa/Madura & 132.187 & 6,95 & 91.281 & 61,87 \\
\hline Sumatra & 476.606 & 24,86 & 27.981 & 18,99 \\
\hline Kalimantan & 539.460 & 28,32 & 6.721 & 4,56 \\
\hline Sulawesi & 189.216 & 9,93 & 10.377 & 7,04 \\
\hline Bali & 5.561 & 0,30 & 2.470 & 1,68 \\
\hline Papua & 421981 & 22,16 & 1.145 & 5,02 \\
\hline Total & $\mathbf{1 . 9 0 5 . 5 6 9}$ & $\mathbf{1 0 0 , 0 0}$ & $\mathbf{1 4 7 . 3 8 4}$ & $\mathbf{1 0 0 , 0 0}$ \\
\hline
\end{tabular}

Salah satu tantangan terbesar di Indonesia adalah tidak meratanya distribusi populasi. Dari tabel di atas dapat kita lihat bahwa pulau Jawa yang memiliki luas permukaan kurang dari $7 \%$ dari luas total, memiliki hampir $62 \%$ populasi.

Buatlah grafik atau diagram yang menunjukan tidak meratanya distribusi populasi di Indonesia.

\section{Gambar 1. Soal No. 8}

Kesalahan yang umum dilakukan siswa dalam menjawab soal ini adalah siswa tidak mampu menunjukan tidak meratanya distribusi populasi di Indonesia sesuai dengan yang diperintahkan dalam soal seperti jawaban dari salah satu siswa di bawah ini.

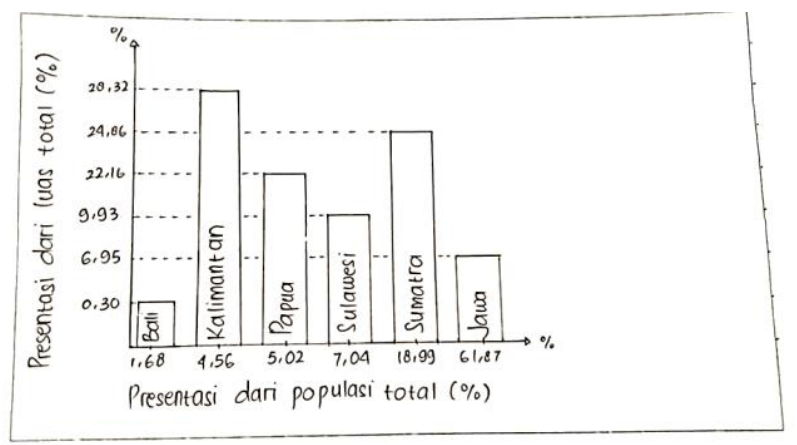

\section{Gambar 2. Contoh Jawaban yang Kurang Tepat dari Soal No. 8}

Dari gambar di atas dapat dilihat bahwa subjek memang mampu membuat diagram batang dari data yang disajikan. Namun subjek hanya memasukan data tentang persentasi luas daerah tanpa membandingkannya dengan persentasi jumlah penduduk untuk tiap daerah. Sehingga, tidak meratanya distribusi penduduk di Indonesia tidak Nampak pada diagram tersebut. Jawaban yang tepat dari soal No. 8 adalah terlihatnya perbandingan persentasi luas daerah terhadap luas wilayah total dan persentasi jumlah penduduk tiap daereah terhadap jumlah penduduk total seperti jawaban berikut. 


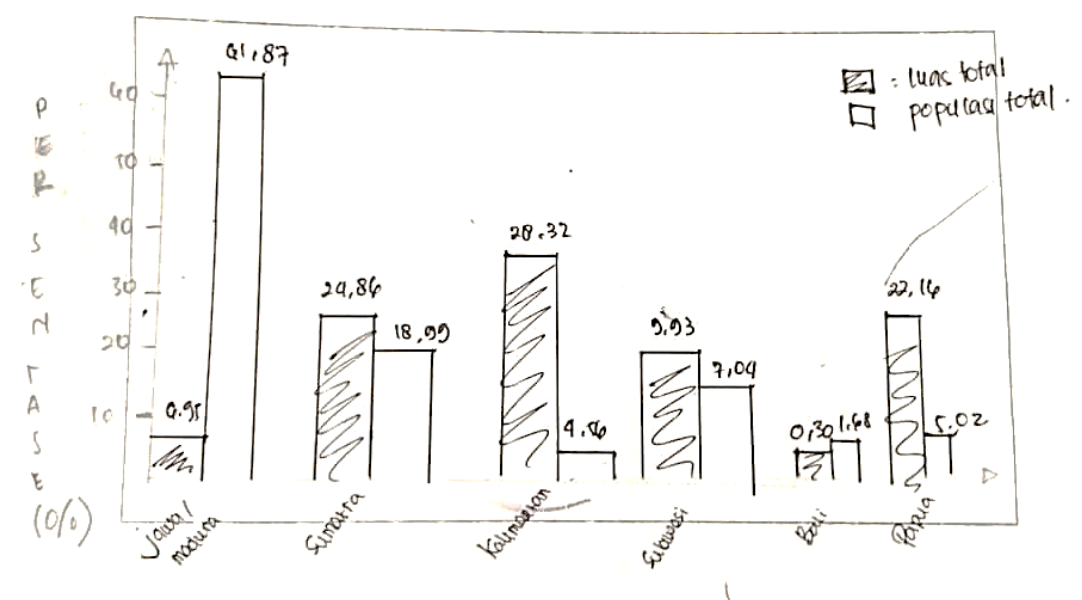

\section{Gambar 3. Contoh Jawaban yang Tepat dari Soal No. 8}

Untuk soal yang paling mudah bagi siswa adalah soal No. 2 dimana 30 siswa dapat menjawab soal ini dengan benar. Pada soal ini, siswa hanya diminta membaca data dari diagram batang yang diberikan seperti yang terlihat pada gambar 4. Pada soal ini, informasi-informasi disajikan secara explisit. Siswa hanya harus dapat membaca diagram dengan teliti.

\section{PENJUALAN CD ALBUM}

Pada bulan Januari, album CD band 'Roker' dan 'Antis' telah dirilis. Pada bulan Februari, album CD band 'Rainbow' dan 'Pencase juga dirilis. Diagram batang berikut menunjukan penjualan $\mathrm{CD}$ album band tersebut dari bulan Januari sampai Juni

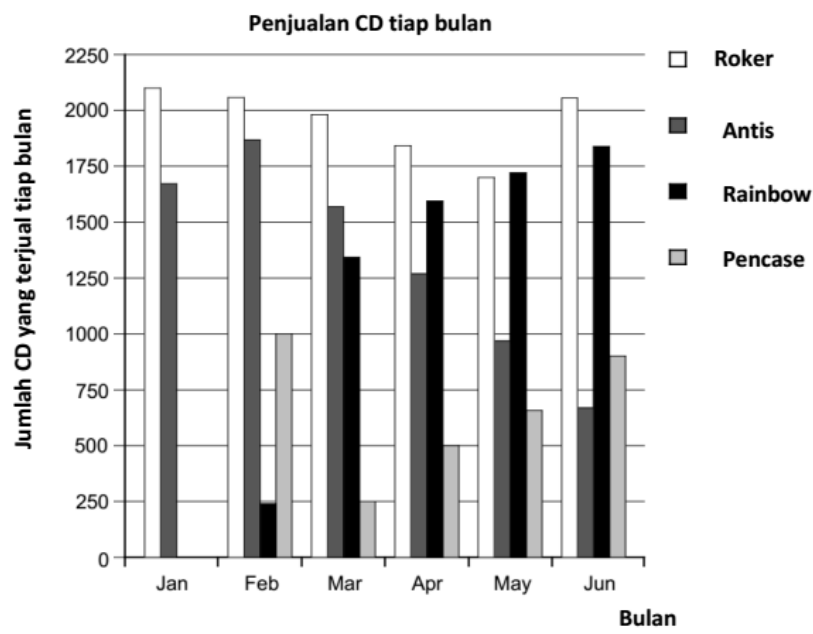

1. Pada bulan apa band Rainbow menjual lebih banyak CD dari band Antis untuk pertama kali?
a. Tidak ada
b. Maret
c. April
d. Mei

Gambar 4. Soal No. 2 
Fakta bahwa sebagian besar subjek dapat menjawab soal ini menunjukan bahwa sebagian besar siswa tidak mengalami kesulitan dalam membaca data. Sebaliknya, fakta bahwa sebagian besar subjek tidak dapat menjawab soal No. 8 dengan tepat menunjukan bahwa subjek masih mengalami kesulitan dalam menyajikan data yang cukup kompleks. Hasil ini sesuai dengan hasil penelitian terdahulu (Nisa', Zulkardi, \& Susanti, 2019) tentang penalaran matematis siswa yang menemukan bahwa diantara indikator penalaran statistis yang ditetapkan (menjelaskan data, organisasi dan pengurangan data, menyajikan data, dan analisis dan interpretasi data), indikator penyajian data lah yang paling sulit bagi siswa.

\section{KESIMPULAN DAN SARAN}

\section{Kesimpulan}

Penelitian ini bertujuan mengukur literasi statistis siswa kelas VIII di SMP Negeri 1 Gresik. Subjek penelitian adalah siswa kelas VIII J. Penilaian validitas tes yang dilakukan oleh dua orang ahli yang memiliki pengalaman dalam penelitian di bidang literasi sebelumnya menunjukan bahwa tes literasi statistis masih membutuhkan beberapa revisi. Setelah revisi dilakukan, tes literasi statistis dinyatakan valid. Perhitungan koefisien reliabilitas dilakukan dengan menggunakan rumus Kuder Richardson (KR 20). Hasil perhitungan ini menunjukan bahwa koefisien reliabilitas adalah 0,57 yang menunjukan tes cukup reliabel. Hasil tes menunjukan bahwa skor rata-rata tes literasi statistis siswa adalah 63,2 $(\mathrm{SD}=8,28)$. Hasil ini mengindikasikan bahwa siswa kelas VIII J SMPN 1 Gresik memiliki kemampuan literasi satistis yang cukup.

\section{Saran}

Dari penelitian ini didapat kesimpulan bahwa siswa kelas VIII J SMPN 1 Gresik memiliki kemampuan literasi satistis yang cukup dengan sebagian besar siswa masih mengalami kesulitan dalam menyajikan data yang kompleks. Untuk itu, disarankan bagi peneliti lain dan guru, perlu melakukan studi yang lebih dalam tentang kesulitan siswa dalam mengerjakan soal-soal literasi statistis. Selain itu, guru juga dapat menerapkan sebuah pendekatan, model, atau metode pembelajaran yang dapat membangun dan meningkatkan literasi statistis siswa.

\section{DAFTAR RUJUKAN}

Arikunto. (2009). Prosedur Penelitian Suatu Pendekatan Praktik Edisi Revisi 6. Jakarta: Rineka Cipta

Badan Standar Pendidkan Nasional. (2019). Buku Saku Ujian Nasional 2019. Diakses dari http://bsnp-indonesia.org/wpcontent/uploads/2019/03/19_02_19-Buku-Saku-UN-2019-revisi-BS20-Feb-1.pdf

Field, Andi. (2009). Discovering Statistic Using SPSS $3^{\text {rd }}$ Edition. London; Sage 
Publicatios.

Lestariningsih. (2019). Profil matematisasi mahasiswa calon guru matematika dalam menyelesaikan soal literasi matematis berdasarkan kemampuan matematika dan gender (Disertasi Program Doktor tidak dipublikasikan). Universitas Negeri Surabaya, Surabaya, Indonesia.

Nisa', K., Zulkardi, \& Susanti, E. (2019). Kemampuan penalaran statistis siswa pada materi penyajian data histogram melalui pembelajaran PMRI. Jurnal Pendidikan Matematika, 13 (1), 21-40

OECD. (2000). Measuring student knowledge and skills. The PISA 2000 Assessment of Reading, Mathematical and Scientific Literacy. Education and Skills.

Diakses

dari http://www.oecd.org/education/school/programmeforinternation alstudentassessmentpisa/33692793.pdf

OECD. (2004). First results from PISA 2003. Executive summary. Diakses dari http://www.oecd.org/education/school/programmeforinternation alstudentassessmentpisa/34002454.pdf

OECD. (2013). PISA 2012 Assessment and Analytical Framework: Mathematics, Reading, Science, Problem solving and Financial literacy. Diakses dari https://www.oecd.org/pisa/pisaproducts/PISA\%202012\%20frame work \%20e-book final.pdf

OECD. (2014). PISA 2012 Results in Focus. What 15-year-olds know what they can do with what they know. Diakses dari https://www.oecd.org/pisa/keyfindings/pisa-2012-results-volume$\underline{\text { I.pdf }}$

Romijin \& Jan-Willem. (2014). Philosophy of Statistics. Standford encyclopedia of philosophy. Diakses dari http://plato.stanford.edu/entries/statistics/

Sariningsih, R.,\& Herdiman. I. (2017). Mengembangkan kemampuan penalaran statistik dan berpikir kreatif matematis mahasiswa melalui pendekatan open ended. Jurnal Riset Pendidikan Matematika, 4 (2), 239246

Sugiyono. (2017). Statistika Untuk Penelitian. Bandung: Alfabeta

Takaria, Johanins \& Talakua, Melfvie. (2018). Kemampuan statistik mahasiswa calon guru ditinjau dari kemampuan awal matematika. Jurnal Kependidikan, 2(2), 395-408 